\title{
Review
}

\section{Leptin: its role in obesity and beyond}

\author{
N.A. Tritos ${ }^{1,2}$, C.S. Mantzoros ${ }^{1}$ \\ ${ }^{1}$ Division of Endocrinology, Beth Israel Deaconess Medical Center, Boston, Massachusetts, USA \\ ${ }^{2}$ Joslin Diabetes Center, Boston, Massachusetts, USA
}

The discovery of leptin, the product of the $o b$ gene [1], has broadened the horizons of research in the regulation of body adiposity and energy balance. This hormone, produced exclusively by the adipose tissue, conveys to the brain information on the size of energy stores and activates hypothalamic centers that regulate energy intake and expenditure [2]. In addition, leptin affects several neuroendocrine mechanisms and regulates multiple hypothalamic-pituitary axes [2]. The realization that the adipose tissue is not merely a storage depot, but also an important endocrine gland, has revived the interest in the "lipostatic theory" of body fat regulation [3] and has opened new opportunities in the investigation and treatment of disorders such as obesity and anorexia nervosa.

In this review, both the biology of leptin secretion and regulation as well as our progress in elucidating the role of leptin in various physiologic and pathophysiologic states are discussed. More specifically, particular emphasis is placed on our current thinking for the role of leptin in physiologic processes, such as control of body adiposity, adaptation to starvation and the onset of puberty as well as the pathogenesis of disorders such as obesity and anorexia nervosa. Finally, some of the important unanswered questions about leptin physiology are discussed and future directions for leptin research are suggested.

Corresponding author: C.S. Mantzoros, M.D., D.Sc., Division of Endocrinology, RN 325, Beth Israel Deaconess Medical Center, 330 Brookline Avenue, Boston, MA 02215, USA

Abbreviations: BMI, Body mass index; C/EBPa, CCAAT/enhancer-binding protein a; PPAR $\gamma$, peroxisome proliferator activating receptor $\gamma$; NIDDM, non-insulin dependent diabetes mellitus; PCOS, polycystic ovary syndrome; cAMP, cyclic adenosine monophosphate; JAK, Janus kinase; STAT, signal transducer and activator of transcription; CNS, central nervous system; NPY, neuropeptide Y; CSF, cerebrospinal fluid; UCP 2 (or 3), uncoupling protein 2 (or 3).

\section{Historic background}

Kennedy [3] first introduced the lipostatic theory of body weight control, according to which the adipose tissue produces a hormone that regulates body size. The elegant work of Hervey [4], based on parabiosis experiments using rats with hypothalamic lesions, suggested almost four decades ago the existence of such a factor that might act on the hypothalamus. Further work by Hausberger [5], and later by Coleman and Hummel [6], also employing the parabiosis paradigm between genetically obese and wild type animals, confirmed and extended Hervey's observations. In these studies, the circulatory systems of two animals were connected, allowing exchange of circulating hormones. Using genetically obese mice, such as the $o b / o b$ and the $d b / d b$ mice, in parabiosis with wild type animals, these investigators postulated the existence of a circulating factor in the wild type mice. They proposed that this substance was absent in $o b / o b$ mice, since $o b / o b$ mice would lose weight when connected to wild type mice. Furthermore, they speculated that $d b / d b$ mice were resistant to the action of the unknown factor, since, on one hand, $d b / d b$ mice in parabiosis with wild type animals fail to lose weight, and, on the other, wild type mice connected to $d b / d b$ mice die of starvation. These findings were interpreted to result from the actions of large amounts of the unknown factor that was appropriately overproduced in response to tissue resistance in $d b$ / $d b$ mice.

All these predictions turned out to be correct when the $o b$ gene was identified by positional cloning using the $o b / o b$ animal model of obesity [1]. Thus, $o b /$ $o b$ animals are obese because they fail to produce leptin [1], whereas $d b / d b$ animals are resistant to leptin because of a mutation in one of the leptin receptors (vide infra) [7, 8]. 


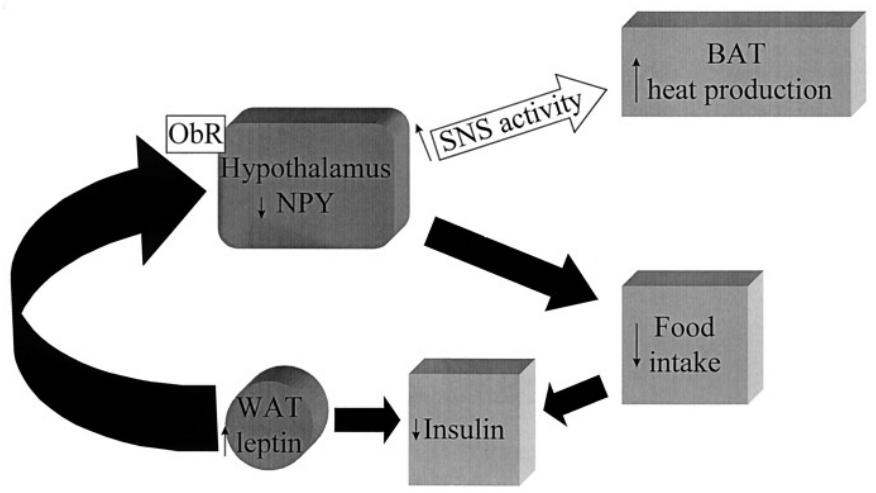

Fig. 1. Model for the regulation of energy balance involves signalling by leptin to the brain on the size of adipose tissue. Leptin decreases NPY expression and levels in the hypothalamic arcuate nuclei, which results in decreased food intake and increased energy expenditure and heat production. A peripheral action of leptin on insulin secretion is also depicted. WAT, White adipose tissue; BAT, brown adipose tissue; ObR, leptin receptor; NPY, neuropeptide Y; SNS, sympathetic nervous system

\section{Leptin: from gene to protein and beyond}

The mouse $o b$ gene, now called the leptin gene (from the Greek leptos: thin), consists of 3 exons and 2 introns and encodes a 4.5 kilobase mRNA [1]. The coding sequence for leptin is contained in exons 2 and 3. Expression of the obese gene is tissue specific, as leptin mRNA is strongly expressed only in white adipose tissue. Demonstration of low level expression of leptin mRNA in brown adipose tissue probably represents contamination from white adipocytes [9]. Leptin mRNA contains a 167 amino acid open reading frame, including a 21 amino acid signal sequence [1]. The human homologue protein is also exclusively secreted from adipose tissue and is $84 \%$ homologous to the mouse protein.

Two different mutations in the mouse leptin gene give rise to the $o b / o b$ phenotype when present in homozygous form [1]. One of the mutations abolishes $o b$ gene transcription and thereby prevents leptin synthesis, whereas the other leads to the production of a truncated, inactive protein. This finding raised the question whether obesity in humans could be due to leptin deficiency. However, although three DNA screening studies of obese populations failed to demonstrate any mutations of the leptin gene [1012], one sequence polymorphism of this gene has been reported in association with extreme obesity [13]. Moreover, the first two individuals with extreme obesity secondary to an inactivating mutation of the $o b$ gene were recently identified [14].

Leptin is secreted from the adipose tissue into the circulation, where it can be measured using an immunoprecipitation assay or a radioimmunoassay [1517]. Recent data suggest that the secretion of leptin is pulsatile [18], and follows a circadian rhythm, with the highest levels observed during the night $[18,19]$. Furthermore, evidence suggests that serum leptin circulates in part bound to transport proteins in the serum of both rodents and humans [20,21]. Interestingly, the proportion of free leptin in the circulation increases with increasing adiposity [20].

Serum leptin concentrations in humans exhibit a sexual dimorphism, with serum leptin levels being considerably higher in women than those in men [22, 23]. Although women tend to have higher fat mass than men for the same body mass index (BMI), this dimorphism appears to occur independently of body adiposity [22, 23]. Two explanations have been proposed for the sexual dimorphism of serum leptin. First, women have a higher ratio of subcutaneous to omental fat mass [24]. Since a significantly higher subcutaneous to omental fat ratio of leptin expression has been demonstrated in women [25], it is conceivable that the higher serum leptin levels in women may reflect these gender variations in regional body fat distribution and leptin expression. Second, it has been suggested that reproductive hormone status may account in part for this dimorphism [22, 23]. This view is further supported by recent studies, which suggested an independent negative association between serum testosterone and serum leptin levels [26-28]. Although the significance of higher serum leptin levels in women is unclear, it is conceivable that serum leptin may serve as a marker of the critical fat stores necessary for reproduction and to meet the energy demands of lactation.

Both in animals and humans, leptin expression and levels increase as the size of the adipose tissue triglyceride stores increases $[15,16,29]$. Specifically, serum leptin is highly correlated with the percentage of body fat and BMI in both humans and rodents [15, 16]. Recent evidence suggests that an increase in caloric intake results in a sharp increase in serum leptin, approximately $40 \%$ over baseline within $12 \mathrm{~h}$, in the absence of changes in body weight $[19,30]$. In contrast, serum leptin concentration in humans does not increase acutely in the postprandial state [30]. On the other hand, both leptin expression and levels decline rapidly in response to starvation, with serum leptin levels starting to decline after $12 \mathrm{~h}$ of fasting and reaching a nadir after $36 \mathrm{~h} \mathrm{[31-33].} \mathrm{Thus,} \mathrm{both}$ body adiposity and acute changes in energy balance appear to regulate leptin expression and levels. However, the precise mechanism mediating these distinct responses to changes in body adiposity and energy balance remains to be elucidated.

In addition to adiposity and energy balance, a number of intrinsic adipocyte factors as well as exogenous, circulating factors may regulate leptin expression and secretion. Thus, the leptin gene promoter is positively regulated by the CCAAT/enhancer-binding protein a $(\mathrm{C} / \mathrm{EBPa})$, a transcription factor important in adipocyte differentiation [34, 35]. In contrast, 


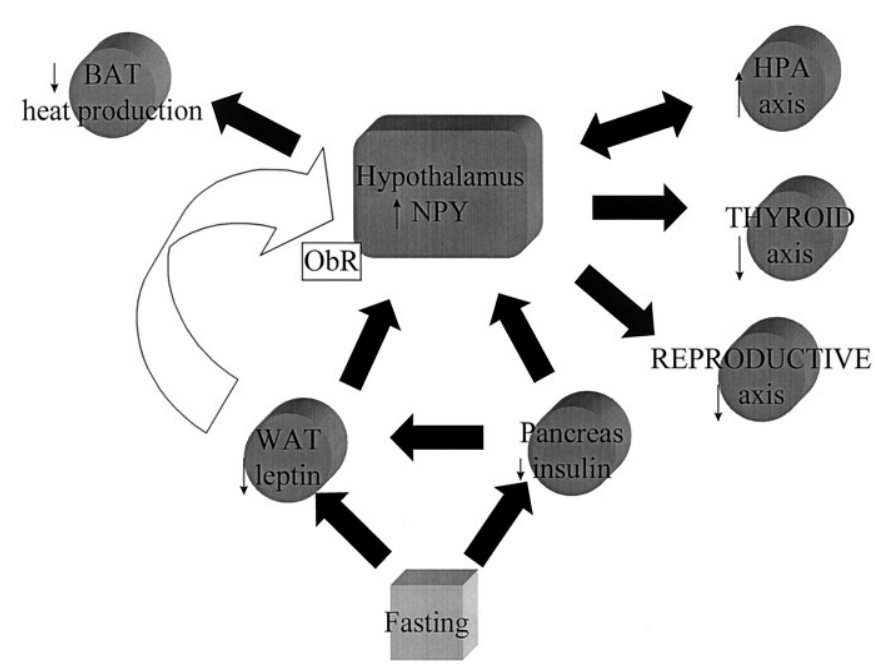

Fig. 2. Model for the neuroendocrine responses to starvation involving diminished leptin and insulin levels in response to fasting. These decreased hormone levels lead to increased NPY expression and levels in the hypothalamic arcuate nuclei, which results in diminished BAT thermogenesis and thyroid and reproductive axis activity as well as increased HPA axis activity. A possible positive feedback cycle between hypothalamic NPY and HPA axis activity is also depicted. WAT, White adipose tissue; BAT, brown adipose tissue; ObR, leptin receptor; NPY, neuropeptide Y; HPA axis, hypothalamic pituitary adrenal axis

thiazolidinediones, such as the novel oral hypoglycaemic agent troglitazone, suppress leptin expression in animal models [36], an action that is probably mediated by their binding to the peroxisome proliferator activating receptor $\gamma$ (PPAR $\gamma$ ), a transcription factor that promotes adipocyte differentiation [36, 37]. Although troglitazone suppresses leptin secretion from human cultured adipocytes [38], it has no effect on leptin production in vivo [37, 39].

In addition to the above factors, the role of hormones in the regulation of leptin expression is being intensively explored. Insulin, the first hormone studied, increases leptin expression and secretion from both rat and human adipocytes in vitro [40, 41]. However, although leptin expression is positively regulated by acute hyperinsulinaemia in rats, this does not appear to be the case in humans [42-44]. In contrast, long-term hyperinsulinaemia appears to increase leptin expression as well as circulating leptin levels in humans $[45,46]$ with leptin expression and levels beginning to increase approximately $48 \mathrm{~h}$ after the onset of hyperinsulinaemia induced by a hyperglycaemic clamp [45]. However, whether hyperinsulinaemia accompanying insulin resistance is associated with higher serum leptin independently of obesity remains unclear. Although hyperinsulinaemia has been associated with higher serum leptin levels in one study of lean men with insulin resistance [47], patients with other insulin resistant states, such as non-insulin-dependent diabetes mellitus (NIDDM) and polycystic ovary syndrome were not found to have higher serum leptin levels [39, 48, 49]. However, glucocorticoids in high doses increase leptin expression in vitro [41, 50] and in vivo [51]. Furthermore, recent data suggest that patients with Cushing's syndrome have higher serum leptin levels independently of body adiposity [52]. Moreover, leptin is positively regulated by cytokines, including the tumour necrosis factor and interleukin $1[49,53,54]$, and is negatively regulated by beta3adrenergic agonists or cyclic AMP (cAMP) [50, 55, 56]. Furthermore, cigarette smoking has been associated with decreased serum leptin levels in humans, possibly reflective of the adrenergic activation that occurs with cigarette smoking ([57], Mantzoros CS, Tritos N, unpublished observations). However, another physiologic "hyperadrenergic" state, hyperthyroidism, was found to have no effect on leptin levels in humans $[58,59]$.

A major breakthrough in leptin research was the identification of the leptin receptor, which occurred within a year from the original report of the leptin $(o b)$ gene cloning $[8,60]$. It is currently known that mice and rats possess five variants of the leptin receptor, generated through alternative splicing of a common mRNA precursor $[8,61]$. The longest of these receptors closely resembles the gp130, the common signal transducing subunit of a group of cytokine receptors, which includes the interleukin 6 , the leukaemia inhibitor factor and the ciliary neurotrophic factor $[8,60]$. Furthermore, the long leptin receptor isoform is most abundantly expressed in the hypothalamus, in keeping with the notion that this part of the brain represents a major site of leptin action [62].

The structure of the long receptor isoform includes a large extracellular domain, a short hydrophobic transmembrane domain, and a fairly short intracellular portion that contains two sequences for binding of a Janus kinase (JAK) [8, 63]. Notably, the JAK belongs to the tyrosine kinase family and has been shown to phosphorylate tyrosine residues in the distal leptin receptor, which allows the binding of one of the signal transducer and activator of transcription (STAT) proteins [64]. Bound STAT proteins are in turn phosphorylated by the JAK, after which they can signal and activate transcription of specific genes. Notably, the $d b / d b$ mouse possesses a mutation that prevents the expression of the long receptor form [7, 8]. Thus, the long receptor isoform appears essential for leptin signalling. The long receptor form is also present in humans and can have sequence polymorphisms, which are of unclear significance [65]. However, it should be stressed that, even though human obesity is believed to be a leptin-resistant state, there have been no reported mutations of the long leptin receptor isoform to date (vide infra).

The other four leptin receptor isoforms do not appear capable of activating the JAK-STAT pathway. In fact, the shortest of these lacks a hydrophobic 
transmembrane domain and probably represents a soluble form of the leptin receptor, possibly a transport protein [8]. Expression of these four receptor isoforms is abundant in the choroid plexus, where they may mediate uptake of leptin across the bloodbrain or blood-cerebrospinal fluid barrier [66]. They are also present in lung and kidney, where they may mediate leptin clearance [67]. However, it is certainly conceivable that one or more of the short receptor isoforms may mediate leptin actions in the periphery through presently unknown mechanisms. Notably, the obese phenotype of both the $f a / f a$ Zucker rats $[68,69]$ and the Koletsky rats [70, 71] results from mutations that equally affect all leptin receptor isoforms. Specifically, $f a / f a$ rats possess a missense mutation in the common extracellular domain of the leptin receptor [68, 69], whereas Koletsky rats have a nonsense mutation that is predicted to lead to total absence of all leptin receptor isoforms [70,71].

\section{Leptin actions in the central nervous system and peripheral tissues}

Leptin derives its name from its ability to induce weight loss in experimental animals. Thus, administration of leptin to $o b / o b$ mice, which either lack the ability to produce leptin or produce a truncated inactive form, results in a sharp decrease in weight, mediated through reduced food intake as well as increased energy expenditure and thermogenesis [72-74]. Furthermore, leptin rescues both the infertile and insulin resistant phenotype of $o b / o b$ mice [74-76]. Normal lean mice also lose weight in response to leptin administration, though the magnitude of this response is not as dramatic as that of the $o b / o b$ mice [74].

Intracerebroventricular administration of leptin results in a more potent response compared with the response to systemic leptin administration, suggesting that the central nervous system (CNS) is a major site of action of leptin [77]. This is further corroborated by the existence of a saturable transport system for leptin across the blood-brain barrier, presumably in the choroid plexus and the hypothalamus [78]. Furthermore, systemic leptin administration to experimental animals has been shown to increase expression of c-fos, a putative marker for neuronal activation, in specific hypothalamic and brainstem areas [79]. Moreover, leptin has been shown to decrease the release of the orexigenic neuropeptide Y (NPY) in vitro as well as NPY expression and hypothalamic NPY levels in vivo [80, 81]. Furthermore, leptin has been shown to rapidly modulate synaptic transmission in arcuate hypothalamic neurons in vitro, many of which contain NPY [82]. It is noteworthy that administration of NPY to rodents results in inhibition of the sympathetic nervous system outflow, decrease in energy expenditure and improved storage of fat
[83]. Thus, regulation of NPY expression may be involved in mediating the effects of leptin in the CNS. However, NPY knockout mice respond to leptin administration to the same extent as wild-type mice, suggesting that other mechanisms besides neuropeptide $\mathrm{Y}$ are also involved in mediating the effects of leptin in the CNS [84]. Moreover, leptin may affect neuroendocrine mechanisms other than regulation of food intake, such as the neuroendocrine responses to starvation and various aspects of hypothalamic-pituitary activity, including triggering the onset of puberty (vide infra).

Furthermore, it is being increasingly appreciated that leptin may also act in the periphery. Thus, leptin has been recently shown to reduce lipid synthesis in cultured adipocytes as well as decrease triglyceride synthesis and increase fatty acid oxidation in normal pancreatic islet cells in short-term culture [85, 86]. Additionally, leptin may modulate insulin secretion as well as insulin-regulated responses. First, it has been suggested that leptin may decrease insulin secretion in vitro [87]. This finding, in combination with the previously mentioned observation that insulin stimulates leptin secretion, suggests the existence of a negative feedback loop between leptin and insulin. Second, one study suggested a decrease in insulin receptor substrate-1 (IRS-1) phosphorylation as well as modulation of downstream effectors of insulin action and up-regulation of gluconeogenesis in hepatocytes exposed to leptin in vitro [88], although other studies have produced conflicting results $[89,90]$. Finally, leptin has been recently shown to stimulate haematopoiesis in vitro [91, 92] and has also been found in human fetuses, where it may be involved in the regulation of fetal haematopoiesis [57, 93, 94].

\section{The role of leptin in health and disease}

The physiologic role of leptin has not yet been fully elucidated. As already mentioned, leptin expression and levels are consistently associated with body adiposity and body mass index in both experimental animals and in humans $[15,16]$. These observations have suggested that leptin may signal the amount of energy stores to the hypothalamus [2]. Thus, leptin may provide important feedback information to the brain, which is necessary for the precise regulation of longterm energy balance. In contrast, the fact that leptin levels do not increase acutely postprandially suggests that leptin is not a classic short-term "satiety factor", that is responsible for the sharp decrease in food intake that accompanies satiety [16, 19].

Nevertheless, the dramatic effects of leptin administration to the leptin-deficient $o b / o b$ mice raised early hopes that human obesity might similarly be a leptin-deficient state. Although deleterious mutations of the leptin $(o b)$ gene have not been found in human 
populations [11], two reports have suggested a linkage of the human leptin $(o b)$ gene with extreme adiposity, suggesting that a small segment of human obesity could be due to leptin deficiency [95, 96]. This view is further corroborated by the recent report of the first two obese individuals with a mutation of the leptin $(o b)$ gene [14]. Furthermore, relative hypoleptinaemia was recently shown to precede weight gain among Pima Indians, suggesting that relative leptin deficiency may be playing a role in the pathogenesis of obesity in this population [97]. In contrast, current evidence from studies of western populations suggests that leptin levels increase appropriately in response to body adiposity in both adults and in children $[16,98]$. This observation has suggested that most cases of human obesity are associated with leptin resistance [16]. Notably, obese individuals have been shown to have a decreased cerebrospinal fluid (CSF) to serum leptin ratio, suggesting that a readily saturable putative transport mechanism across the blood brain barrier may account for the apparent leptin resistance observed in human obese individuals [99-101]. Furthermore, it has been suggested that modest hypercortisolism in association with simple obesity may contribute to leptin resistance among the obese [102]. Other possible explanations for the leptin resistance in the obese include abnormal protein binding of serum leptin, deficient leptin receptor or post-receptor transducing mechanisms or, alternatively, the presence of critical defects in other central pathways that regulate energy balance. Finally, whether impaired pulsatility of leptin secretion is associated with leptin resistance in the obese remains to be demonstrated [18].

Starvation is another condition where leptin appears to play an important role. More specifically, starvation results in a sharp decline in leptin levels both in experimental animals and in humans, that is out of proportion to body adiposity changes [31-33]. Thus, an acute drop in serum leptin could be responsible for the documented decrease in energy expenditure that accompanies weight loss [103]. Such changes in energy expenditure may account for the clinically observed difficulty that obese people face when attempting to lose weight. Thus, it appears that the body may be employing leptin as a rapidly acting defence mechanism that aims to maintain the "status quo" in terms of energy balance and body size, although this remains to be definitively demonstrated.

Besides regulation of energy balance, leptin appears to influence several neuroendocrine mechanisms. Thus, administration of leptin to starving normal mice blunts the neuroendocrine responses that are typically observed in association with starvation, including decreased gonadal and thyroid axis activity as well as increased adrenal axis activity [104]. Furthermore, leptin was recently shown to prevent the fasting-induced suppression of thyrotropin releasing hormone expression in the rodent hypothalamus [105]. Additionally, leptin may be involved in the regulation of growth hormone secretion [106]. It should also be noted that hypothalamic NPY expression is increased in starvation, presumably in response to decreased leptin and insulin levels [83]. Even though the evolutionary purpose of leptin is unclear, it has been proposed [2] that the decline of leptin expression and levels in starvation may have evolved as an adaptive mechanism to an environment where food availability is limited. Such a decline in leptin levels leads to energy conservation by decreasing thyroid hormone-induced thermogenesis and avoiding the energy demands of pregnancy and lactation, while at the same time increasing secretion of beneficial stress glucocorticoids that mobilize energy stores [2].

Additionally, recent experimental data support an emerging role for leptin in the regulation of multiple hypothalamic-pituitary functions in states other than starvation. Thus, leptin blunts the hypoglycaemia-induced corticotrophin releasing hormone release from isolated hypothalamic neurons [107] and the activity of the hypothalamic-pituitary-adrenal axis in humans varies inversely to the serum leptin levels [18]. These findings, in combination with the previously mentioned data, according to which dexamethasone stimulates leptin secretion, suggest the existence of a negative feedback loop between leptin and glucocorticoids. Moreover, the administration of leptin to $o b / o b$ mice, which are normally infertile, results in central activation of the hypothalamic-pituitarygonadal axis and corrects the sterility defect $[75,76]$. Furthermore, leptin has been shown to accelerate the onset of puberty in normal female mice [108]. Recently, a sharp peak in serum leptin was found to precede the onset of puberty in boys [109], suggesting that leptin may be the long-awaited signal that triggers the onset of puberty upon attainment of a critical body adiposity threshold in the absence of acute changes in energy balance [110].

The role of leptin is also being actively investigated in the pathogenesis of other disorders of body weight regulation, such as anorexia nervosa. Both serum and CSF leptin levels correlate with the BMI of patients with anorexia nervosa [111, 112]. Moreover, a longitudinal study of patients with anorexia nervosa suggested that the CSF to serum leptin ratio is highest prior to weight gain and decreases as the patients gain weight [112], indicating that CSF uptake of leptin is highest when serum leptin is low, as previously suggested in studies involving obese individuals [100, 112]. Importantly, patients with anorexia nervosa appear to normalize their CSF and serum leptin levels before their BMI returns to normal, which may explain their clinically observed resistance to body weight gain [112]. However, it remains to be clarified whether altered leptin transport across the blood brain barrier is inherent to subjects predisposed to 
anorexia nervosa and plays a primary role in the pathogenesis of this disease or whether altered leptin transport is a secondary epiphenomenon accompanying weight loss.

Another clinical syndrome where leptin might be involved is insulin resistance. As already mentioned, insulin resistance is a consistent feature of $o b / o b$ mice and improves in response to leptin administration [74], which may be partly explained by the significant weight loss that leptin-treated $o b / o b$ mice demonstrate. Furthermore, recent data suggest that leptin improves insulin sensitivity of normal rats [113]. Such findings have suggested a possible role for leptin in the pathogenesis of insulin resistance in humans. However, screening of the coding region of the leptin $(o b)$ gene of obese patients with NIDDM failed to demonstrate any mutations [12]. Furthermore, two separate studies showed that serum leptin levels were not different among either NIDDM patients or women with the polycystic ovary syndrome compared with non-diabetic control subjects [37, 39]. Thus, it is clear that the role of leptin in the pathogenesis of insulin resistance requires further investigation.

\section{Future directions}

Despite the rapid advances in our knowledge of leptin, as evidenced by the exponential increase in relevant publications over the past two and a half years, many questions remain unanswered. At a fundamental level, the mechanisms governing the regulation of leptin expression and secretion must be further elucidated. In particular, how the size of triglyceride adipose tissue stores modulates leptin expression remains a mystery. The role of circulating hormones, paracrine tissue factors, intracellular transcription factors and other mediators in the regulation of leptin expression and secretion must be clearly established. The mechanisms responsible for leptin pulsatility, leptin binding in the circulation, leptin transport across the blood brain barrier as well as signal transduction through the leptin receptors must be refined. Finally, both the neuroendocrine as well as the emerging peripheral actions of leptin must be further clarified.

At a physiologic and clinical level, even more answers are sorely needed. Thus, the role of leptin in the control of physiologic processes, such as the regulation of energy balance, the control of various aspects of hypothalamic-pituitary activity (including the onset of puberty and the neuroendocrine response to starvation) and the regulation of haemopoiesis, must be definitively established. Importantly, the involvement of leptin in the pathogenesis of conditions such as obesity, anorexia nervosa, bulimia, insulin resistance and polycystic ovary syndrome must be further elucidated in various populations and under various experimental conditions.

Furthermore, although promising, the therapeutic potential of leptin as a treatment of obesity is unclear and is just beginning to be explored. Thus, studies are underway to establish the safety and efficacy of leptin administration to obese human subjects. Moreover, both the elucidation of the crystal structure of a human mutant leptin protein and the localization of leptin activity to the amino acid residues 106-140 raise hopes for the development of smaller, more potent peptide analogues of leptin that may have therapeutic potential or can be used to clarify leptin physiology in vivo $[114,115]$.

No doubt, the enthusiasm that followed the discovery of leptin has been a tremendous thrust behind the precipitous growth of research in leptin, obesity and in energy homeostasis in general. Thus, the recent cloning of both the human and the murine uncoupling protein homologue genes (UCP 2 and 3) raise hopes that the molecular mechanisms governing thermogenesis in humans, some of which may be regulated by leptin, will soon be unveiled [116]. We hope that current and future research efforts will not only provide much needed answers to the questions posed above, but they will also lead to tangible benefits for the large and increasing segment of our population that is striving to control excessive body weight.

Note added in proof. Recent data suggest that leptin is also produced by human placenta (117). The possible physiologic (placental hormone that could influence fetal growth and haematopoiesis) or pathophysiologic role (marker of gestational trophoblastic neoplasms) of placenta derived leptin remains to be fully elucidated.

Acknowledgements. This work was supported in part by the A.S. Onassis Foundation

\section{References}

1. Zhang Y, Proenca R, Maffei M, et al. (1994) Positional cloning of the mouse obese gene and its human homologue. Nature 372: 425-432

2. Flier JS (1997) Leptin expression and action: new experimental paradigms. Proc Natl Acad Sci USA 94: 4242-4245

3. Kennedy GC (1953) The role of depot fat in the hypothalamic control of food intake in the rat. Proc R Soc 140: 578-592

4. Hervey GR (1958) The effects of lesions in the hypothalamus in parabiotic rats. J Physiol 145: 336-352

5. Hausberger FX (1959) Parabiosis and transplantation experiments in hereditarily obese mice. Anat Rec 130: 313

6. Coleman DL, Hummel KP (1969) Effects of parabiosis of normal with genetically diabetic mice. Am J Physiol 217: 1298-1304

7. Chen H, Charlat O, Tartaglia LA, et al. (1996) Evidence that the diabetes gene encodes the leptin receptor: identification of a mutation in the leptin receptor gene in $\mathrm{db} / \mathrm{db}$ mice. Cell 84: 491-495 
8. Lee GH, Proenca R, Montez JM, et al. (1996) Abnormal splicing of the leptin receptor in diabetic mice. Nature 379: 632-635

9. Cinti S, Frederich RC, Zingaretti MC, et al. (1997) Immunohistochemical localization of leptin and uncoupling protein in white and adipose tissue. Endocrinology 138: 797-804

10. Considine RV, Considine EL, Williams CJ, et al. (1995) Evidence against either a premature stop codon or the absence of obese gene mRNA in human obesity. J Clin Invest 95: 2986-2988

11. Maffei M, Stoffel M, Barone M, et al. (1996) Absence of mutations in the human $O B$ gene in obese/diabetic individuals. Diabetes 45: 679-682

12. Niki T, Mori H, Tamori Y, et al. (1996) Human obese gene: molecular screening in Japanese and Asian Indian NIDDM patients associated with obesity. Diabetes 45: 675-678

13. Considine RV, Considine EL, Williams CJ, et al. (1996) Mutation screening and identification of a sequence variation in the human $o b$ gene coding. Biochem Biophys Res Comm 220: 735-739

14. Montague CT, Farooqi IS, Whitehead MH, et al. (1997) Congenital leptin deficiency is associated with severe early-onset obesity in humans. Nature 387: 903-907

15. Maffei M, Halaas J, Ravussin E, et al. (1995) Leptin levels in human and rodent: measurement of plasma leptin and $o b$ mRNA in obese and weight-reduced subjects. Nat Med 1: 1155-1161

16. Considine R, Sinha MK, Heiman ML, et al. (1996) Serum immunoreactive-leptin concentrations in normal-weight and obese humans. N Engl J Med 334: 292-295

17. Ma Z, Gingerich RL, Santiago JV, et al. (1996) Radioimmunoassay of leptin in human plasma. Clin Chem 42: 942-946

18. Licinio J, Mantzoros C, Negrao AB, et al. (1997) Human leptin levels are pulsatile and inversely related to pituitary-adrenal function. Nat Med 3: 575-579

19. Sinha MK, Ohannesian JP, Heiman ML, et al. (1996) Nocturnal rise of leptin in lean, obese, and non-insulin-dependent diabetes mellitus subjects. J Clin Invest 97: 1344-1347

20. Houseknecht KL, Mantzoros CS, Kuliawat R, et al. (1996) Evidence for leptin binding to proteins in serum of rodents and humans: modulation with obesity. Diabetes 45: 1638-1643

21. Sinha MK, Opentanova I, Ohannesian JP, et al. (1996) Evidence for free and bound leptin in human circulation. $\mathbf{J}$ Clin Invest 98: 1277-1282

22. Havel PJ, Kasim-Karakas S, Dubuc GR, et al. (1996) Gender differences in plasma leptin concentrations. Nat Med 2: 949-950

23. Rosenbaum M, Nicolson M, Hirsch J, et al. (1996) Effects of gender, body composition, and menopause on plasma concentrations of leptin. JCEM 81: 3424-3427

24. Bouchard C, Despres JP, Mauriege P (1993) Genetic and nongenetic determinants of regional fat distribution. Endocr Rev 14: 72-93

25. Montague CT, Prins JB, Sanders L, et al. (1997) Depot and sex specific differences in human leptin mRNA expression: implications for the control of regional fat distribution. Diabetes 46: 342-347

26. Jockenhovel F, Blum WF, Vogel E, et al. (1997) Testosterone substitution normalizes elevated serum leptin levels in hypogonadal men. J Clin Endocrinol Metab 82: 25102513

27. Behre HM, Simoni M, Nieschlag E (1997) Strong association between serum levels of leptin and testosterone in men. Clin Endocrinol 47: 237-240
28. Nystrom F, Ekman B, Osterlund M, et al. (1997) Serum leptin concentrations in a normal population and in $\mathrm{GH}$ deficiency: negative correlation with testosterone in men and effects of GH treatment. Clin Endocrinol 47: 191198

29. Frederich RC, Hamann A, Anderson S, et al. (1995) Leptin levels reflect body lipid content in mice: evidence for diet-induced resistance to leptin action. Nat Med 1: 1311-1314

30. Kolaczynski JW, Ohannesian J, Considine RV, et al. (1996) Response of leptin to short-term and prolonged overfeeding in humans. J Clin Endocrinol Metab 81: 4162-4165

31. Kolaczynski JW, Considine RV, Ohannesian J, et al. (1996) Responses of leptin to short-term fasting and refeeding in humans: a link with ketogenesis but not ketones themselves. Diabetes 45: 1511-1515

32. Trayhurn P, Thomas MEA, Duncan JS, et al. (1995) Effects of fasting and refeeding on $O b$ gene expression in white adipose tissue of lean and obese mice. FEBS Lett 368: 488-490

33. Boden G, Chen X, Mozzoli M, et al. (1996) Effect of fasting on serum leptin in normal human subjects. J Clin Endocrinol Metab 81: 3419-3423

34. He Y, Chen H, Quon MJ, et al. (1995) The mouse obese gene: genomic organization, promoter activity, and activation by CCAAT/enhancer-binding protein a. J Biol Chem 270: 28887-28891

35. Miller SG, De Vos P, Guerre-Millo M, et al. (1996) The adipocyte specific transcription factor $\mathrm{C} / \mathrm{EBPa}$ modulates human $o b$ gene expression. Proc Natl Acad Sci USA 93: $5507-5511$

36. De Vos P, Lefebvre AM, Miller SG, et al. (1996) Thiazolidinediones repress $o b$ gene expression in rodents via activation of peroxisome proliferator-activated receptor gamma. J Clin Invest 98: 1004-1009

37. Nolan JJ, Olefsky JM, Nyce MR, et al. (1996) Effect of troglitazone on leptin production: studies in vitro and in human subjects. Diabetes 45: 1276-1278

38. Kallen CB, Lazar MA (1996) Antidiabetic thiazolidinediones inhibit leptin $(o b)$ gene expression in 3T3-L1 adipocytes. Proc Natl Acad Sci USA 93: 5793-5796

39. Mantzoros CS, Dunaif A, Flier JS (1997) Leptin concentrations in the polycystic ovary syndrome. J Clin Endocrinol Metab 82: 1687-1691

40. Rentsch J, Chiesi M (1996) Regulation of $o b$ gene mRNA levels in cultured adipocytes. FEBS Lett 379: 55-59

41. Wabitsch M, Jensen PB, Blum WF, et al. (1996) Insulin and cortisol promote leptin production in cultured human fat cells. Diabetes 45: 1435-1438

42. Saladin R, De Vos P, Guerre-Mille M, et al. (1995) Transient increase in obese gene expression after food intake or insulin administration. Nature 377: 527-529

43. Pratley RE, Nicolson M, Bogardus C, et al. (1996) Effects of acute hyperinsulinaemia on plasma leptin concentrations in insulin-sensitive and insulin-resistant Pima Indians. J Clin Endocrinol Metab 81: 4418-4421

44. Vidal H, Auboeuf D, De Vos P, et al. (1996) The expression of $o b$ gene is not acutely regulated by insulin and fasting in human abdominal subcutaneous adipose tissue. $\mathrm{J}$ Clin Invest 98: 251-255

45. Kolaczynski JW, Nyce MR, Considine RV, et al. (1996) Acute and chronic effect of insulin on leptin production in humans. Diabetes 45: 699-701

46. Dagogo-Jack S, Fanelli C, Paramore D, et al. (1996) Plasma leptin and insulin relationships in obese and nonobese humans. Diabetes 45: 695-698 
47. Segal KR, Landt M, Klein S (1996) Relationship between insulin sensitivity and plasma leptin concentration in lean and obese men. Diabetes 45: 988-991

48. Haffner SM, Stern MP, Miettinen H, et al. (1996) Leptin concentrations in diabetic and nondiabetic MexicanAmericans. Diabetes 45: 822-824

49. Mantzoros CS, Moschos S, Avramopoulos I, et al. (1997) Leptin concentrations in relation to BMI and activation of the TNF alpha system in humans. J Clin Endocrinol Metab 82: 3408-3413

50. Slieker LJ, Sloop KW, Surface PL, et al. (1995) Regulation of expression of $o b$ mRNA and protein by glucocorticoids and cAMP. J Biol Chem 271:5301-5304

51. Papaspyrou-Rao S, Schneider SH, Petersen RN, et al. (1997) Dexamethasone increases leptin expression in humans in vivo. J Clin Endocrinol Metab 82: 1635-1637

52. Masuzaki H, Ogawa Y, Hosoda K, et al. (1997) Glucocorticoid regulation of leptin synthesis and secretion in humans: elevated plasma leptin levels in Cushing's syndrome. J Clin Endocrinol Metab 82: 2542-2547

53. Grunfeld C, Zhao C, Fuller J (1996) Endotoxin and cytokines induce expression of leptin, the $o b$ gene product, in hamsters: a role for leptin in the anorexia of infection. J Clin Invest 97: 2151-2157

54. Sarraf P, Frederick RC, Turner EM, et al. (1997) Multiple cytokines and acute inflammation raise mouse leptin levels: potential role in inflammatory anorexia. J Exp Med 185: $171-175$

55. Gettys TW, Harkness PJ, Watson PM, et al. (1996) The beta 3 adrenergic receptor inhibits insulin-stimulated leptin secretion from isolated rat adipocytes. Endocrinology 137: 4054-4057

56. Mantzoros CS, Qu D, Frederich RC, et al. (1996) Activation of beta 3 adrenergic receptors suppresses leptin expression and mediates a leptin independent inhibition of food intake in mice. Diabetes 45: 909-914

57. Mantzoros CS, Varvarigou A, Kaklamani V, et al. (1997) Effect of birth weight and maternal smoking on cord blood leptin concentrations of full-term and preterm newborns. J Clin Endocrinol Metab 82: 2856-2861

58. Mantzoros CS, Rosen HR, Greenspan SL, et al. (1997) Short-term hyperthyroidism has no effect on leptin concentration in man. J Clin Endocrinol Metab 82:497-499

59. Valcavi R, Zini M, Peino F, et al. (1997) Influence of thyroid status on serum immunoreactive leptin levels. J Clin Endocrinol Metab 82: 1632-1634

60. Tartaglia LA, Dembski M, Weng X, et al. (1995) Identification and expression cloning of a leptin receptor, OB-R. Cell 83: 1263-1271

61. Takaya K, Ogawa Y, Isse N, et al. (1996) Molecular cloning of rat leptin receptor isoform cDNAs - identification of a missense mutation in Zucker fatty rats. Biochem Biophys Res Comm 225: 75-83

62. Mercer JG, Hogard N, Williams LM, et al. (1996) Localization of leptin receptor mRNA and the long form splice variant $(\mathrm{Ob}-\mathrm{Rb})$ in mouse hypothalamus and adjacent brain regions by in situ hybridization. FEBS Lett 387: 113-116

63. Bauman H, Morella KK, White DW, et al. (1996) The fulllength leptin receptor has signalling capabilities of interleukin-6-type cytokine receptors. Proc Nat Acad Sci USA 93: 8374-8378

64. Vaisse C, Halaas JL, Horvath CM, et al. (1996) Leptin activation of Stat 3 in the hypothalamus of wild type and $o b /$ $o b$ mice but not $d b / d b$ mice. Nat Gen 14: 95-97

65. Considine RV, Considine EL, Williams CJ, et al. (1996) The hypothalamic leptin receptor in humans: identification of incidental sequence polymorphisms and absence of the $d b / d b$ mouse and $f a / f a$ rat mutations. Diabetes 19: 992-994

66. Tartaglia LA (1997) The leptin receptor. J Biol Chem 272: 6093-6096

67. Cumin F, Baum HP, Levens N (1996) Leptin is cleared from the circulation primarily by the kidney. Int J Obes Relat Metab Disord 20: 1120-1126

68. Chua SC, White DW, Wu-Peng S, et al. (1996) Phenotype of fatty due to Gln269Pro mutation in the leptin receptor (Lepr). Diabetes 45: 1141-1143

69. Phillips MS, Liu Q, Hammond HA, et al. (1996) Leptin receptor missense mutation in the fatty Zucker rat. Nat Genet 13: 18-19

70. Takaya K, Ogawa Y, Hiraoka J, et al. (1996) Nonsense mutation of leptin receptor in the obese spontaneously hypertensive Koletsky rat. Nat Genet 14: 130-131

71. Wu-Peng XS, Chua SC, Okada N, et al. (1997) Phenotype of the obese Koletsky (f) rat due to Tyr763Stop mutation in the extracellular domain of the leptin receptor (Lepr). Diabetes 46: 513-518

72. Campfield LA, Smith FJ, Guisez Y, et al. (1995) Recombinant mouse $o b$ protein: evidence for a peripheral signal linking adiposity and central neural networks. Science 269: 546-549

73. Halaas JL, Gajiwala KS, Maffei M, et al. (1995) Weightreducing effects of the plasma protein encoded by the obese gene. Science 269: 543-546

74. Pelleymounter MA, Cullen MJ, Baker MB, et al. (1995) Effects of the obese gene product on body weight regulation in $o b / o b$ mice. Science 269: 540-543

75. Barash IA, Cheung CC, Weigle DS, et al. (1996) Leptin is a metabolic signal to the reproductive system. Endocrinology 137: 3144-3147

76. Chehab FF, Lim ME, Lu R (1996) Correction of the sterility defect in homozygous obese female mice by treatment with the human recombinant leptin. Nat Genet 12: 318 320

77. Schwartz MW, Seeley RJ, Campfield LA, et al. (1996) Identification of targets of leptin action in rat hypothalamus. J Clin Invest 98: 1101-1106

78. Banks WA, Kastin AJ, Huang W, et al. (1996) Leptin enters the brain by a saturable system independent of insulin. Peptides 17: 305-311

79. Elmquist JK, Ahima RS, Maratos-Flier E, et al. (1997) Leptin activates neurons in ventrobasal hypothalamus and brainstem. Endocrinology 138: 839-842

80. Stephens TW, Basinski M, Bristow PK, et al. (1995) The role of neuropeptide $\mathrm{Y}$ in the antiobesity action of the obese gene product. Nature 377: 530-532

81. Wang Q, Bing C, Al-Barazanji K, et al. (1997) Interactions between leptin and hypothalamic neuropeptide $\mathrm{Y}$ neurons in the control of food intake and energy homeostasis in the rat. Diabetes 46: 335-341

82. Glaum SR, Hara M, Bindokas VP, et al. (1996) Leptin, the obese gene product, rapidly modulates synaptic transmission in the hypothalamus. Mol Pharmacol 50: 230-235

83. Schwartz MW, Seeley RJ (1997) Neuroendocrine responses to starvation and weight loss. N Engl J Med 336: 1802 1811

84. Erickson JC, Clegg KE, Palmiter RD (1996) Sensitivity to leptin and susceptibility to seizures of mice lacking neuropeptide Y. Nature 381: 415-418

85. Bai Y, Zhang S, Kim KS, et al. (1996) Obese gene expression alters the ability of 30A5 preadipocytes to respond to lipogenic hormones. J Biol Chem 271: 13939_ 13942 
86. Shimabukuro M, Koyama K, Chen G, et al. (1997) Direct antidiabetic effect of leptin through triglyceride depletion of tissues. Proc Natl Acad Sci USA 94: 4637-4641

87. Kiefer TJ, Heller RS, Leech CA, et al. (1997) Leptin suppression of insulin secretion by the activation of ATP-sensitive $\mathrm{K}$ channels in pancreatic beta cells. Diabetes 46: 1087-1093

88. Cohen B, Novick D, Rubinstein M (1996) Modulation of insulin activities by leptin. Science 274: 1185-1188

89. Berti L, Kellerer M, Capp E, et al. (1997) Leptin stimulates glucose transport and glycogen synthesis in C2C12 myotubes: evidence for a PI3-kinase mediated effect. Diabetologia 40: 606-609

90. Takahasi Y, Okimura Y, Mizuno I, et al. (1997) Leptin induces mitogen-activated protein kinase-dependent proliferation of C3H10T1/2 cells. J Biol Chem 272: 12897-12900

91. Cioffi JA, Shafer AW, Zupancic TJ, et al. (1996) Novel $219 / O B$ receptor isoforms: possible role of leptin in haematopoiesis and reproduction. Nat Med 2: 585-589

92. Bennett BD, Solar GP, Yuan JQ, et al. (1997) A role for leptin and its cognate receptor in haematopoiesis. Curr Biol 6: 1170-1180

93. Matsuda J, Yokota I, Iida M, et al. (1997) Serum leptin concentration in cord blood: relationship to birth weight and gender. J Clin Endocrinol Metab 82: 1642-1644

94. Sivan E, Lin WM, Homko CJ, et al. (1997) Leptin is present in human cord blood. Diabetes 46: 917-919

95. Clement K, Garner C, Hager J, et al. (1996) Indication for linkage of the human $O B$ gene region with extreme obesity. Diabetes 45: 687-690

96. Reed DR, Ding Y, Xu W, et al. (1996) Extreme obesity may be linked to markers flanking the human $O B$ gene. Diabetes 45: 691-694

97. Ravussin E, Pratley RE, Maffei M, et al. (1997) Relatively low plasma leptin concentrations precede weight gain in Pima Indians. Nat Med 3: 238-240

98. Hassink SG, Sheslow DV, de Lancey E, et al. (1996) Serum leptin in children with obesity: relationship to gender and development. Pediatrics 98: 201-203

99. Caro JF, Kolaczynski JW, Nyce MR, et al. (1996) Decreased cerebrospinal fluid/serum leptin ration in obesity: a possible mechanism for leptin resistance. Lancet 348: 159-161

100. Caro JF, Sinha MK, Kolaczynski JW, et al. (1996) Leptin: the tale of an obesity gene. Diabetes 45 : 1455-1462

101. Schwartz MW, Peskind E, Raskind M, et al. (1996) Cerebrospinal fluid leptin levels: relationship to plasma levels and to adiposity in humans. Nat Med 2: 589-593

102. Zakrzewska KE, Cusin I, Sainsbury A, et al. (1997) Glucocorticoids as counterregulatory hormones of leptin-towards an understanding of leptin resistance. Diabetes 46: 717-719

103. Leibel RL, Rosenbaum M, Hirsch J (1995) Changes in energy expenditure resulting from altered body weight. $\mathrm{N}$ Engl J Med 332: 621-628
104. Ahima RS, Prabakaran D, Mantzoros CS, et al. (1996) Role of leptin in the neuroendocrine response to fasting. Nature 382: 250-252

105. Legradi G, Emerson CH, Ahima RS, et al. (1997) Leptin prevents fasting-induced suppression of prothyrotropinreleasing hormone mRNA in neurons of the hypothalamic paraventricular nucleus. Endocrinology 138: 2569-2576

106. Carro E, Senaris R, Considine RV, et al. (1997) Regulation of in vivo growth hormone secretion by leptin. Endocrinology 138: 2203-2205

107. Heiman ML, Ahima RS, Craft LS, et al. (1997) Leptin inhibition of the hypothalamic-pituitary-adrenal axis in response to stress. Endocrinology 3859-3863

108. Ahima RS, Dushay J, Flier SN, et al. (1997) Leptin accelerates the onset of puberty in normal female mice. J Clin Invest 99:391-395

109. Mantzoros CS, Flier JS, Rogol AD (1997) A longitudinal assessment of hormonal and physical alterations during normal puberty in boys vs rising leptin levels may signal the onset of puberty. J Clin Endocrinol Metab 82: 10661070

110. Frisch RE, McArthus JW (1974) Menstrual cycles: fatness as a determinant of minimum weight necessary for their maintenance or onset. Science 185: 949-951

111. Ferron F, Considine RV, Peino R, et al. (1997) Serum leptin concentrations in patients with anorexia nervosa, bulimia nervosa and non-specific eating disorders correlate with the body mass index but are independent of the respective disease. Clin Endocrinol 46: 289-293

112. Mantzoros CS, Flier JS, Lesem MD, et al. (1997) Cerebrospinal fluid leptin in anorexia nervosa: correlation with nutritional status and potential role in resistance to weight gain. J Clin Endocrinol Metab 82: 1845-1851

113. Sivitz WI, Walsh SA, Morgan DA, et al. (1997) Effects of leptin on insulin sensitivity in normal mice. Endocrinology 138: 3395-3401

114. Grasso P, Leinung MC, Ingher SP, et al. (1997) In vivo effects of leptin-related synthetic peptides on body weight and food intake in female $o b / o b$ mice: localization of leptin activity to domains between amino acid residues 106140. Endocrinology 138: 1413-1418

115. Zhang F, Basinski MB, Beals JM, et al. (1997) Crystal structure of the obese protein leptin E-100. Nature 387: 206-209

116. Gimeno R, Dembski M, Weng X, et al. (1997) Cloning and characterization of an uncoupling protein homolog-a potential molecular mediator of human thermogenesis. Diabetes 46: 900-906

117. Masuzaki H, Ogawa Y, Sagawa N et al. (1997) Nonadipose tissue production of leptin: Leptin as a novel placenta-derived hormone in humans. Nature Medicine 3: 10291033 